\title{
Flood-Inundation Maps for the Saluda River from Old Easley Bridge Road to Saluda Lake Dam near Greenville, South Carolina
}

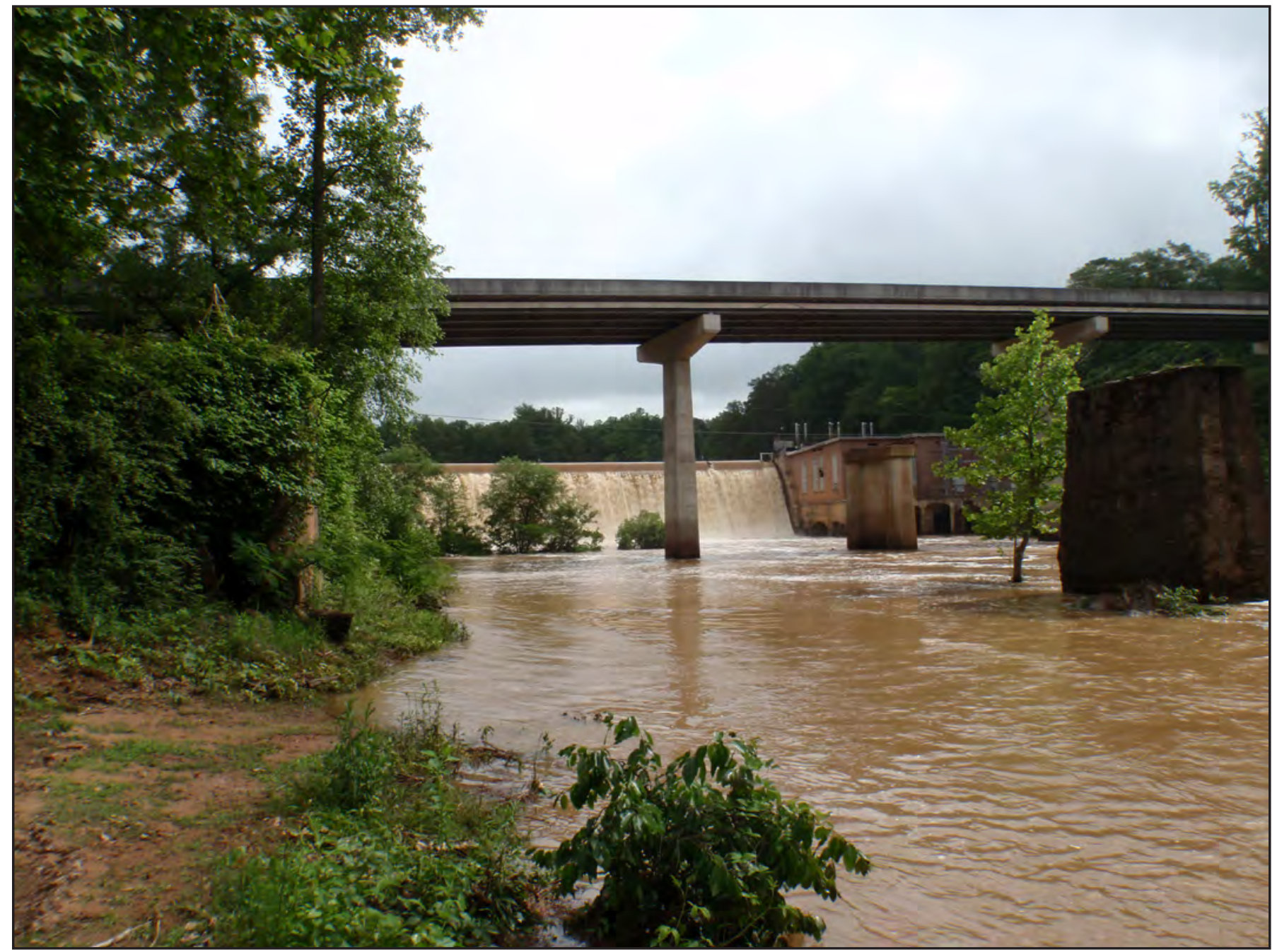

Pamphlet to accompany

Scientific Investigations Map 3244

U.S. Department of the Interior

U.S. Geological Survey 
Cover. Photograph of Saluda Lake Dam and Saluda Dam Road (S-63) crossing the Saluda River near Greenville, South Carolina. Photograph by Wladmir Guimaraes, U.S. Geological Survey. 


\section{Flood-Inundation Maps for the Saluda River from Old Easley Bridge Road to Saluda Lake Dam near Greenville, South Carolina}

By Stephen T. Benedict, Andral W. Caldwell, and Jimmy M. Clark

Pamphlet to accompany

Scientific Investigations Map 3244 


\section{U.S. Department of the Interior \\ KEN SALAZAR, Secretary}

\section{U.S. Geological Survey \\ Suzette M. Kimball, Acting Director}

U.S. Geological Survey, Reston, Virginia: 2013

For more information on the USGS - the Federal source for science about the Earth, its natural and living resources, natural hazards, and the environment, visit http://www.usgs.gov or call 1-888-ASK-USGS.

For an overview of USGS information products, including maps, imagery, and publications, visit http://www.usgs.gov/pubprod

To order this and other USGS information products, visit http://store.usgs.gov

Any use of trade, product, or firm names is for descriptive purposes only and does not imply endorsement by the U.S. Government.

Although this report is in the public domain, permission must be secured from the individual copyright owners to reproduce any copyrighted materials contained within this report.

Suggested citation:

Benedict, S.T., Caldwell, A.W., and Clark, J.M., 2013, Flood-inundation maps for the Saluda River from Old Easley Bridge Road to Saluda Lake Dam near Greenville, South Carolina: U.S. Geological Survey Scientific Investigations Map 3244, 15 sheets, 7-p. pamphlet. 


\section{Contents}

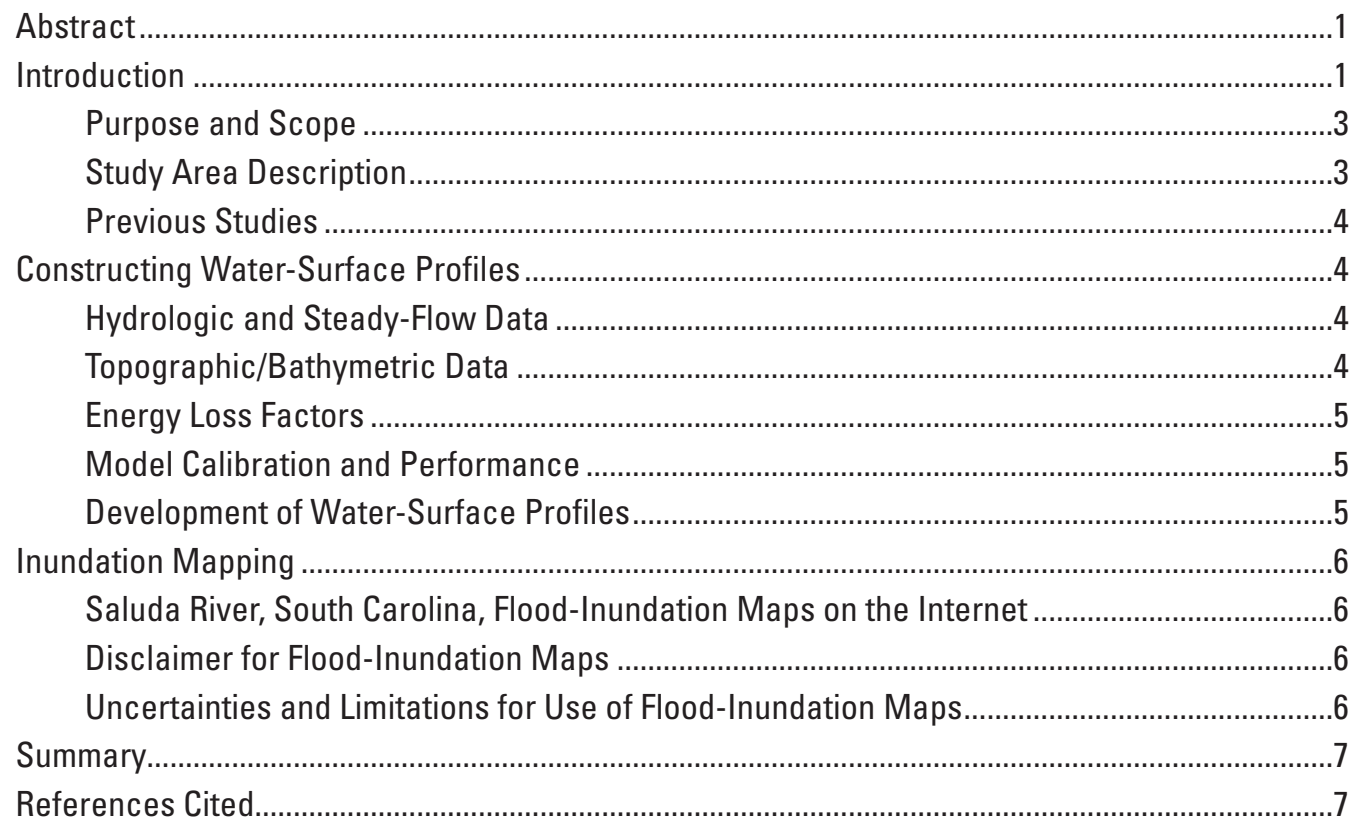

\section{Figure}

1. Map showing locations of study reach for the Saluda River, U.S. Geological Survey streamgage, and National Weather Service forecast point

\section{Tables}

1. Site information for the U.S. Geological Survey streamgage on the study reach, Saluda River near Greenville, South Carolina...

2. Estimates of peak streamflow for a 1.0-percent annual exceedance probability for selected locations on the Saluda River

3. Stages, water-surface elevations, and corresponding streamflow estimates based on rating no. 11 at the U.S. Geological Survey streamgage station 02162500, Saluda River near Greenville, South Carolina 


\section{Sheets}

[Sheets and additional materials are available online at $h$ ttp://pubs.usgs.gov/sim/3244/]

1-15. Maps showing flood-inundation for the Saluda River from Old Easley Bridge Road to Saluda Lake Dam near Greenville, South Carolina, corresponding to a stage at U.S. Geological Survey streamgage Saluda River near Greenville, South Carolina (02162500) -

1. Stage of 6.0 feet and an elevation of 803.2 feet

2. Stage of 7.0 feet and an elevation of 804.2 feet

3. Stage of 8.0 feet and an elevation of 805.2 feet

4. Stage of 9.0 feet and an elevation of 806.2 feet

5. Stage of 10.0 feet and an elevation of 807.2 feet

6. Stage of 11.0 feet and an elevation of 808.2 feet

7. Stage of 12.0 feet and an elevation of 809.2 feet

8. Stage of 13.0 feet and an elevation of 810.2 feet

9. Stage of 14.0 feet and an elevation of 811.2 feet

10. Stage of 15.0 feet and an elevation of 812.2 feet

11. Stage of 16.0 feet and an elevation of 813.2 feet

12. Stage of 17.0 feet and an elevation of 814.2 feet

13. Stage of 18.0 feet and an elevation of 815.2 feet

14. Stage of 19.0 feet and an elevation of 816.2 feet

15. Stage of 20.0 feet and an elevation of 817.2 feet 


\section{Conversion Factors and Datums}

\begin{tabular}{lcl}
\hline \multicolumn{1}{c}{ Multiply } & By & \multicolumn{1}{c}{ To obtain } \\
\hline inch (in.) & Length & millimeter $(\mathrm{mm})$ \\
foot (ft) & 25.4 & meter $(\mathrm{m})$ \\
mile (mi) & 0.3048 & kilometer $(\mathrm{km})$ \\
\hline & 1.609 & \\
\hline square foot $\left(\mathrm{ft}^{2}\right)$ & Area & square meter $\left(\mathrm{m}^{2}\right)$ \\
square mile $\left(\mathrm{mi}^{2}\right)$ & 0.0929 & square kilometer $\left(\mathrm{km}^{2}\right)$ \\
\hline & 2.590 & \\
\hline cubic foot per second $\left(\mathrm{ft}^{3} / \mathrm{s}\right)$ & Flow rate & cubic meter per second $\left(\mathrm{m}^{3} / \mathrm{s}\right)$ \\
\hline & 0.02832 & \\
\hline foot per mile $(\mathrm{ft} / \mathrm{mi})$ & Hydraulic gradient & meter per kilometer $(\mathrm{m} / \mathrm{km})$ \\
\hline
\end{tabular}

Vertical coordinate information is referenced to the North American Vertical Datum of 1988 (NAVD 88).

Horizontal coordinate information is referenced to the North American Datum of 1983 (NAD 83).

Elevation, as used in this report, refers to the distance above NAVD 88.

Stage, as used in this report, is the height of the water surface above an arbitrary datum established at the gage (gage datum).

\section{Acronyms}

$\begin{array}{ll}\text { AHPS } & \text { Advanced Hydrologic Prediction Service } \\ \text { DFIRM } & \text { Digital Flood Insurance Rate Map } \\ \text { FEMA } & \text { Federal Emergency Management Agency } \\ \text { FIS } & \text { Flood Insurance Study } \\ \text { GIS } & \text { geographic information system } \\ \text { LiDAR } & \text { light detection and ranging } \\ \text { NWS } & \text { National Weather Service } \\ \text { RMSE } & \text { Root Mean Square Error } \\ \text { USGS } & \text { U.S. Geological Survey }\end{array}$

\section{Acknowledgments}

The authors wish to thank South Carolina Electric and Gas for funding the operation and maintenance of the gage used for this study. Special thanks are given to Sara Brown of the U.S Army Corps of Engineers for her technical guidance and support and to the National Weather Service for their continued support to the USGS flood-inundation mapping initiative. 



\title{
Flood-Inundation Maps for the Saluda River from Old Easley Bridge Road to Saluda Lake Dam near Greenville, South Carolina
}

\author{
By Stephen T. Benedict, Andral W. Caldwell, and Jimmy M. Clark
}

\section{Abstract}

Digital flood-inundation maps for a 3.95-mile reach of the Saluda River from approximately 815 feet downstream from Old Easley Bridge Road to approximately 150 feet downstream from Saluda Lake Dam near Greenville, South Carolina, were developed by the U.S. Geological Survey (USGS). The inundation maps, which can be accessed through the USGS Flood Inundation Mapping Science Web site at http://water.usgs.gov/osw/flood_inundation/, depict estimates of the areal extent and depth of flooding corresponding to selected water levels (stages) at the USGS streamgage at Saluda River near Greenville, South Carolina (station 02162500). Current conditions at the USGS streamgage may be obtained through the National Water Information System Web site at http://waterdata.usgs.gov/sc/nwis/ $u v /$ site_no $=02162500 \&$ PARAmeter_cd $=00065,00060,00062$. The National Weather Service (NWS) forecasts flood hydrographs at many places that are often collocated with USGS streamgages. Forecasted peak-stage information is available on the Internet at the NWS Advanced Hydrologic Prediction Service (AHPS) flood-warning system Web site (http:// water.weather.gov/ahps/) and may be used in conjunction with the maps developed in this study to show predicted areas of flood inundation.

In this study, flood profiles were computed for the stream reach by means of a one-dimensional step-backwater model. The model was calibrated using the most current stagestreamflow relations at USGS streamgage station 02162500 , Saluda River near Greenville, South Carolina. The hydraulic model was then used to determine water-surface profiles for flood stages at 1.0-foot intervals referenced to the streamgage datum and ranging from approximately bankfull to 2 feet higher than the highest recorded water level at the streamgage. The simulated water-surface profiles were then exported to a geographic information system, ArcGIS, and combined with a digital elevation model (derived from Light Detection and Ranging [LiDAR] data with a 0.6-foot vertical Root Mean Square Error [RMSE] and a 3.0-foot horizontal RMSE), using HEC-GeoRAS tools in order to delineate the area flooded at each water level.
The availability of these maps, along with real-time stage data from the USGS streamgage station 02162500 and forecasted stream stages from the NWS, can provide emergency management personnel and residents with information that is critical during flood-response and flood-recovery activities, such as evacuations, road closures, and disaster declarations.

\section{Introduction}

The Saluda River flows generally southeastward along the boundary between Greenville and Pickens Counties near the outskirts of the city limits of Greenville and Easley, South Carolina (SC) (fig. 1). Greenville and Pickens Counties have a combined population of about 580,000 and the nearby urban communities of Greenville and Easley have estimated populations of 58,400 and 20,000, respectively (U.S. Census Bureau, 2012a). Historical records at the U.S. Geological Survey (USGS) streamgage station 02162500, Saluda River near Greenville, SC (fig. 1) indicate that the Saluda River experienced large floods in 1949, 1961, 1964, 1965, 1995, and most recently in 2004. The 2004 floodwaters inundated yards and the crawl spaces of several homes located along the study reach (Pat Tanner, National Weather Service, oral commun., September 25, 2012). In the neighboring Reedy River basin, damage costs for the 2004 flood in downtown Greenville were reported to be $\$ 5.8$ million (Burrus and Pelissier, 2011). Flood plains along the Saluda River study reach are moderately developed and contain a mix of residential and commercial structures.

Prior to this study, local government officials have relied on several information sources (all of which are available on the Internet) to make decisions on how to best alert the public and mitigate flood damages. One source is the Federal Emergency Management Agency (FEMA) Flood Insurance Study (FIS) Digital Flood Insurance Rate Maps (DFIRMs) for Greenville and Pickens Counties, dated December 2, 2004, and April 16, 2008, respectively (Federal Emergency Management Agency, 2004, 2008). A second source of information is the USGS streamgage, Saluda River near Greenville, South Carolina (station 02162500), from which current or historical water levels (stage) are available for this streamgage. A third 


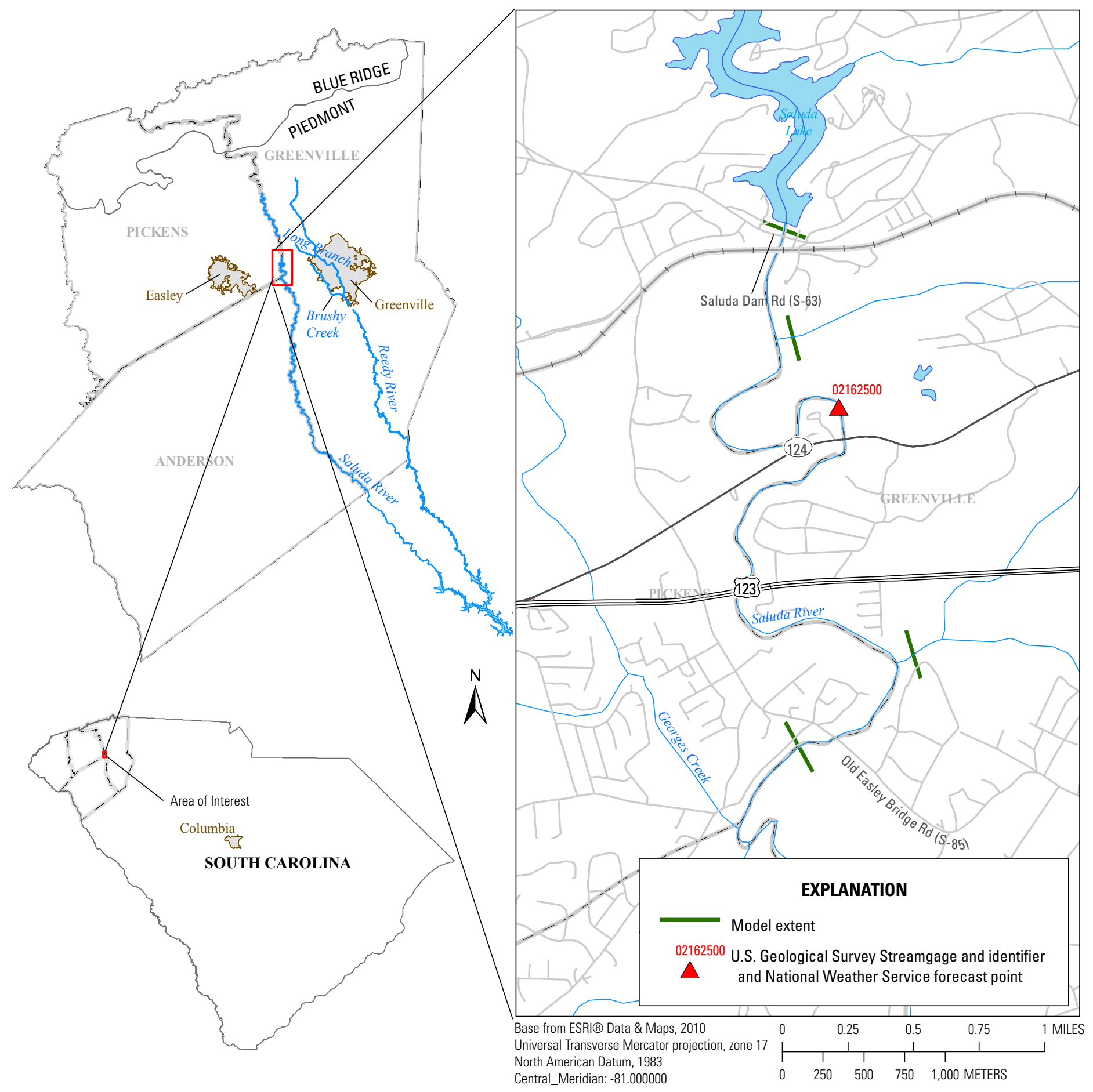

Figure 1. Locations of study reach for the Saluda River, U.S. Geological Survey streamgage, and National Weather Service forecast point. 
source is the National Weather Service (NWS) forecasts of flood hydrographs showing peak stage at the USGS streamgage through the NWS Advanced Hydrologic Production Service (AHPS) Web site (http://water.weather.gov/ahps/).

Although USGS current stage and NWS forecast stage data are particularly useful for residents in the immediate vicinity of a streamgage, the data are of limited use to residents farther upstream or downstream because the watersurface elevation is not constant along the entire stream channel. Additionally, FEMA and State emergency management mitigation teams or property owners typically lack information related to water depth at locations other than near USGS streamgages or NWS flood-forecast points. To provide information on floods in areas upstream and downstream from the USGS streamgage, the USGS conducted a study to produce digital flood-inundation maps for a 3.95-mile (mi) reach of the Saluda River. These digital flood-inundation maps show an estimate of the modeled flood-water extent and depth on the land surface and are tied to USGS and NWS floodforecast sites to help officials to make timely operational and public safety decisions during floods. The flood-inundation maps show estimated flood-inundated areas overlain on highresolution, aerial imagery of the study area for each of the water-surface profiles generated by the HEC-RAS hydraulic model (U.S. Army Corps of Engineers, Hydrologic Engineering Center, 2010).

\section{Purpose and Scope}

The purpose of this report is to describe the development of a series of estimated flood-inundation maps for the Saluda River near Greenville, SC. The maps and other useful flood information are available on the USGS Flood Inundation Mapping Science Web site at http://water.usgs.gov/osw/ flood_inundation/and the previously mentioned NWS AHPS Web site. Internet users can select estimated inundation maps that correspond closely to (1) current stages at the USGS streamgage (02162500), (2) the NWS forecasted peak stage, or (3) other desired stream stages.
The scope of the study was limited to a 3.95-mi reach of the Saluda River from approximately 815 feet ( $\mathrm{ft}$ ) downstream from Old Easley Bridge Road (Road S-85) to approximately $150 \mathrm{ft}$ downstream from Saluda Lake Dam (fig. 1). Tasks specific to development of the maps were (1) analysis of stage and flow data for station 02162500 (table 1), (2) collection of topographic data and geometric data (for bridges) throughout the study reach, (3) determination of energy-loss factors (roughness coefficients) in the stream channel and flood plain, (4) computation of water-surface profiles using the U.S. Army Corps of Engineers' HEC-RAS computer program (U.S. Army Corps of Engineers, Hydrologic Engineering Center, 2010), (5) production of estimated flood-inundation maps at various stream stages using the U.S. Army Corps of Engineers' HECGeoRas software (U.S. Army Corps of Engineers, Hydrologic Engineering Center, 2009) within a geographic information system (ArcGIS), and (6) development of a Web site interface that links to USGS real-time streamgage information and NWS forecasted peak stage to facilitate the display of userselected flood-inundation maps on the Internet.

Methods used are generally cited from previously published reports (Bales and others, 2007; Whitehead and Ostheimer, 2009). Maps were produced for water levels referenced to the water-surface elevation (stage) at the USGS streamgage Saluda River near Greenville, SC (station 02162500) and range from approximately bankfull to $2 \mathrm{ft}$ above the maximum observed water level at the streamgage.

\section{Study Area Description}

The Saluda River is in northwest South Carolina and drains part of the Blue Ridge and Piedmont Physiographic Provinces. The drainage area ranges from 302 square miles $\left(\mathrm{mi}^{2}\right)$ at the downstream study limit to $296 \mathrm{mi}^{2}$ at the upstream study limit. The drainage area at the USGS streamgage station 02162500 is $298 \mathrm{mi}^{2}$. The headwaters originate in Greenville and Pickens Counties, and the river flows generally southeastward along the boundary between Greenville and Pickens Counties. There are no major tributaries to the Saluda River that join the main stem as it flows near the outskirts of the city

Table 1. Site information for the U.S. Geological Survey streamgage on the study reach, Saluda River near Greenville, South Carolina. $\left[\mathrm{mi}^{2}\right.$, square mile; ${ }^{\circ}$, degree, ', minute; ", second; ft, feet]

\begin{tabular}{|c|c|c|c|c|c|c|}
\hline Station name & $\begin{array}{l}\text { Station } \\
\text { number }\end{array}$ & $\begin{array}{l}\text { Drainage } \\
\text { area } \\
\left(\mathrm{mi}^{2}\right)\end{array}$ & Latitude & Longitude & Period of record & $\begin{array}{l}\text { Maximum } \\
\text { recorded stage at } \\
\text { gage and date }\end{array}$ \\
\hline $\begin{array}{l}\text { Saluda River near Greenville, } \\
\text { South Carolina }\end{array}$ & 02162500 & ${ }^{1} 298$ & $34^{\circ} 50^{\prime} 32^{\prime \prime}$ & $82^{\circ} 28^{\prime} 51^{\prime \prime}$ & $\begin{array}{l}\text { Jan. } 1942 \text { to Sep. } 1978 \text {, Oct. } 1978 \text { to } \\
\text { Jan. } 1990 \text { (partial-record site), } \\
\text { Feb. } 1990 \text { to current year (2012) }\end{array}$ & $\begin{array}{c}{ }^{2} 19.38 \mathrm{ft} \\
\text { Oct. } 7,1949\end{array}$ \\
\hline
\end{tabular}

${ }^{1}$ The previous published drainage area for the U.S. Geological Survey streamgage station 02162500 was $295 \mathrm{mi}^{2}$, but was updated in July 2012 to the current value of $298 \mathrm{mi}^{2}$.

${ }^{2}$ The 1949 flow is based on an indirect flow computation. The upper end of the current rating (no. 11) is based on a high flow measurement from the 2004 flood and does not pass directly through the 1949 indirect flow measurement. Rating no. 11 is considered a reliable rating for current conditions; therefore, a stage of $18 \mathrm{ft}$ corresponds to the flow of 11,000 cubic feet per second for rating no. 11. 
limits of Greenville and Easley, SC. The basin terrain generally consists of rolling hills. The study reach is approximately $3.95 \mathrm{mi}$ long, has an average top-of-bank channel width of about $120 \mathrm{ft}$ and an average channel slope of 4.1 feet per mile (ft/mi). The lower half of the study reach has a flatter channel slope of approximately $2.1 \mathrm{ft} / \mathrm{mi}$. The land contiguous to the study reach is classified as a mixture of housing developments, forest, and pasture. The study area is located $7 \mathrm{mi}$ west of Greenville, SC, and 5 mi east of Easley, SC (fig. 1). The population for Greenville has increased by 2.1 percent from April 1, 2010, to July 1, 2011, while the population of Easley has increased by 0.3 percent for the same time period (U.S. Census Bureau, 2012b). Along the study reach, there are four bridges and one railroad that cross the channel and the adjacent flood plain.

\section{Previous Studies}

The current DFIRM for Greenville County was published December 2, 2004, and the DFIRM for Pickens County was published April 16, 2008 (Federal Emergency Management Agency, 2008). The DFIRMs were used to check the inundation extent for a streamflow that was close to the 1-percent annual exceedance probability. A HEC-RAS model of the Saluda River, which was used in the 2008 publication of the Pickens County DFIRM, was obtained from FEMA on August 21, 2012, and was used to help verify the results of the USGS HEC-RAS model along the Saluda River study reach for this investigation. The HEC-RAS model was a Limited Detailed Study model that was tied into a model that was published in the 1992 FIS (Maria Cox, South Carolina Department of Natural Resources, written commun., October 31, 2012). The HEC-RAS model obtained from FEMA was based on 2002 topographic map data and assumed a constant flow of 12,930 cubic feet per second $\left(\mathrm{ft}^{3} / \mathrm{s}\right)$ over the same study reach for the USGS investigation (table 2).

Table 2. Estimates of peak streamflow for a 1.0-percent annual exceedance probability for selected locations on the Saluda River (from Federal Emergency Management Agency, 2008).

$\left[\mathrm{mi}^{2}\right.$, square miles; $\mathrm{ft}^{3} / \mathrm{s}$, cubic feet per second; USGS, U.S. Geological Survey]

\begin{tabular}{|c|c|c|c|}
\hline Location on Saluda River & $\begin{array}{l}\text { Drainage } \\
\text { area } \\
\left(\mathrm{mi}^{2}\right)\end{array}$ & $\begin{array}{l}\text { Streamflow } \\
\text { estimate } \\
\left(\mathrm{ft}^{3} / \mathrm{s}\right)\end{array}$ & $\begin{array}{c}\text { Percentage } \\
\text { of total } \\
\text { discharge }\end{array}$ \\
\hline $\begin{array}{l}\text { Downstream study limit } \\
\text { ( } 815 \text { feet downstream } \\
\text { from Old Easley } \\
\text { Bridge Road })\end{array}$ & 302 & 12,930 & 100 \\
\hline $\begin{array}{l}\text { USGS streamgage station } \\
02162500\end{array}$ & ${ }^{1} 298$ & 12,930 & 100 \\
\hline $\begin{array}{l}\text { Upstream study limit } \\
\text { (150 feet downstream } \\
\text { from Saluda Lake Dam) }\end{array}$ & 296 & 12,930 & 100 \\
\hline
\end{tabular}

${ }^{1}$ The previous published drainage area for the U.S. Geological Survey streamgage station 02162500 was $295 \mathrm{mi}^{2}$, but was updated in July 2012 to the current value of $298 \mathrm{mi}^{2}$.

\section{Constructing Water-Surface Profiles}

The water-surface profiles used to produce the 15 flood-inundation maps in this study were computed using HEC-RAS, version 4.1.0 (U.S. Army Corps of Engineers, Hydrologic Engineering Center, 2010). HEC-RAS is a one-dimensional step-backwater model for simulation of water-surface profiles with steady-state (gradually varied) or unsteady-state flow computation options. The HEC-RAS analysis for this study was completed using the steady-state flow computation option.

\section{Hydrologic and Steady-Flow Data}

The study area hydrologic network consists of one streamgage, station 02162500 (fig. 1; table 1). Water level (stage) is measured continuously at this streamgage, and continuous records of streamflow are computed from the stage record. All water-surface elevations are referenced to the North American Vertical Datum of 1988 (NAVD 88). The streamgage is equipped with a satellite radio transmitter that allows data to be transmitted routinely and made available on the Internet within an hour of collection.

Steady-flow data consisted of flow regime, boundary conditions (normal depth), and peak discharge. The steadyflow data for the study reach were determined by using streamflow values with known stages obtained from actual field measurements of streamflow and stage-streamflow relations at USGS streamgage station 02162500 . The Saluda Lake Dam, located at the upstream end of the study reach, has minimal influence on higher streamflows (U.S. Geological Survey, 2012) and, therefore, was assumed to have negligible influence on the higher flows used in this investigation. Additionally, because the upstream to downstream change in drainage area for the study reach is small (296 to $302 \mathrm{mi}^{2}$ ), constant flows were assumed throughout the reach.

\section{Topographic/Bathymetric Data}

Channel cross sections were developed from USGS field surveys that were conducted in May and June 2012. These cross sections provided detailed elevation data in the channel below the water surface, on the streambanks, and a short distance into the flood plain. A combination of survey techniques were used to collect these data. Channel elevation data below the water surface were collected using hydroacoustic instrumentation to measure depth. Flood-plain, top-of-bank, and water-surface elevation data at each cross section were determined by using a standard surveying instrument; elevations were determined by using closed level-loop surveying techniques from a reference datum established with a Trimble RTKGPS with a 3-millimeter ( $\mathrm{mm}$ ) horizontal accuracy and 5 -mm vertical accuracy in static mode (Trimble, 2012). Light Detection and Ranging (LiDAR) data with $0.6-\mathrm{ft}$ vertical root-mean square error (RMSE) and 3-ft horizontal RMSE 
were used to provide digital elevation data for the portions of the cross sections that were above the water surface. The LiDAR data were collected in 2011 for the South Carolina LiDAR Consortium and accuracy tested at a 95-percent confidence level (South Carolina Department of Natural Resources, 2010).

Various manmade drainage structures (bridges and roadway embankments) in and along the stream affect or have the potential to affect water-surface elevations during flooding. There are five bridge crossings along the study reach (in downstream to upstream order): Old Easley Bridge Road (Road S-85), Route U.S. 123, Route S.C. 124, a railroad, and Saluda Dam Road (Road S-63). The railroad and Road S-63 bridges located near the upper limits of the study reach are long bridges that span the flood plain and create no constriction of flow; therefore, these bridges were not modeled as flow contractions. Both of these bridges have piers in the channel, however, and the Manning's roughness coefficients were increased (based on guidance from Arcement and Schneider [1989]) in the HEC-RAS model at these cross sections to account for losses associated with the piers. To properly account for these features at the remaining three bridges, structural dimensions were measured and surveyed in the field concurrently with the stream channel surveys and were modeled using standard HEC-RAS techniques for modeling bridges. A detailed description of the methods used to acquire and process the topographic and bathymetric data can be found in Bales and others (2007).

\section{Energy Loss Factors}

Field observations and aerial photographs were used to select initial (pre-calibration) Manning's roughness coefficients (" $n$ " values) for energy (friction) loss calculations. The final Manning's $n$ values used ranged from 0.048 to 0.062 for the main channel and from 0.06 to 0.16 for the overbank areas modeled in this analysis.

\section{Model Calibration and Performance}

The HEC-RAS hydraulic model was calibrated to the most current (2012) stage-streamflow relation at streamgage station 02162500 . The peak streamflow for the period of record at the streamgage occurred during the 1949 flood with an estimated flow of $11,000 \mathrm{ft}^{3} / \mathrm{s}$ (based on an indirect flow computation) with an estimated stage of about $19.38 \mathrm{ft}$. (NOTE: The upper end of the current rating [no. 11] is based on a high-flow measurement from the 2004 flood and does not pass directly through the 1949 indirect flow measurement. Rating no. 11 is considered a reliable rating for current conditions and, therefore, a stage of $18 \mathrm{ft}$ corresponds to the flow of $11,000 \mathrm{ft}^{3} / \mathrm{s}$ for rating no. 11.) The model calibration was limited to flows that were approximately equal to or less than the upper bound of the measured data. Model calibration was accomplished by adjusting Manning's $n$ values and, in some cases, changing the channel cross section until the results of the hydraulic computations closely agreed with the known flood flow and stage values at the streamgage. Differences between measured and simulated water levels for specified flows were equal to or less than $0.10 \mathrm{ft}$. The South Carolina Department of Transportation will typically identify high-water marks associated with historical events on their bridge plans, and such data can be used for model verification. However, the bridge plans associated with bridges along the study reach had no historical high-water marks that could be correlated to the Saluda River streamgage. Because the streamgage was the only point for calibration along the study reach, the uncertainty associated with the model calibration will increase with distance from the gage. This should be kept in mind when reviewing results associated with this investigation. Details on techniques used in model development and calibration can be found in Bales and others (2007).

\section{Development of Water-Surface Profiles}

Profiles were developed for 15 stages at $1.0-\mathrm{ft}$ intervals between 6.0 and $20.0 \mathrm{ft}$ as referenced to the USGS streamgage station 02162500 . Streamflows corresponding to the various stages were obtained from the most current stage-streamflow relation (rating no. 11) at the Saluda River streamgage. Streamflows for all profiles (table 3) at USGS streamgage station 02162500 on the Saluda River were assumed to be constant because of the small change in drainage area over the reach.

Table 3. Stages, water-surface elevations, and corresponding streamflow estimates based on rating no. 11 at the U.S. Geological Survey streamgage station 02162500, Saluda River near Greenville, South Carolina.

[NAVD 88, North American Vertical Datum of 1988]

\begin{tabular}{cccc}
$\begin{array}{c}\text { Stage, } \\
\text { in feet above } \\
\text { gage datum }\end{array}$ & $\begin{array}{c}\text { Elevation, } \\
\text { in feet, } \\
\text { NAVD 88 }\end{array}$ & $\begin{array}{c}\text { Estimated } \\
\text { streamflow, } \\
\text { in cubic feet } \\
\text { per second }\end{array}$ & $\begin{array}{c}\text { Map } \\
\text { sheet } \\
\text { number }\end{array}$ \\
\hline 6.0 & 803.2 & 2,810 & 1 \\
7.0 & 804.2 & 3,620 & 2 \\
8.0 & 805.2 & 4,390 & 3 \\
9.0 & 806.2 & 5,130 & 4 \\
10.0 & 807.2 & 5,840 & 5 \\
11.0 & 808.2 & 6,530 & 6 \\
12.0 & 809.2 & 7,210 & 7 \\
13.0 & 810.2 & 7,870 & 8 \\
14.0 & 811.2 & 8,520 & 9 \\
15.0 & 812.2 & 9,150 & 10 \\
16.0 & 813.2 & 9,780 & 11 \\
17.0 & 814.2 & 10,400 & 12 \\
18.0 & 815.2 & 11,000 & 13 \\
19.0 & 816.2 & 12,000 & 14 \\
20.0 & 817.2 & 13,200 & 15 \\
\hline
\end{tabular}




\section{Inundation Mapping}

Flood-inundation maps were created based on the Saluda River near Greenville, SC, streamgage station 02162500 , which has been designated as an NWS flood-forecast point (GSLS1). The maps were created in a geographic information system by combining the water-surface profiles and digital elevation model data. Estimated flood-inundation boundaries for each simulated profile were developed with HEC-GeoRAS software (U.S. Army Corps of Engineers, Hydrologic Engineering Center, 2009). HEC-GeoRAS is a set of procedures, tools, and utilities for processing geospatial data in ArcGIS by using a graphical user interface (Whitehead and Ostheimer, 2009). The interface allows the preparation of geometric data for import into HEC-RAS and processes simulation results exported from HEC-RAS (U.S. Army Corps of Engineers, Hydrologic Engineering Center, 2010). USGS personnel then modified the HEC-GeoRAS results to ensure a hydraulically reasonable transition of the boundary between modeled cross sections relative to the contour data for the land surface (Whitehead and Ostheimer, 2009). The maps show estimated flood-inundated areas overlain on high-resolution aerial imagery of the study area for each of the water-surface profiles that were generated by the hydraulic model.

\section{Saluda River, South Carolina, Flood-Inundation Maps on the Internet}

A USGS Flood Inundation Mapping Science Web site has been established to provide a portal for USGS floodinundation information to the public at http://water.usgs.gov/ osw/flood_inundation/. That Web portal has a link (http:// wim.usgs.gov/FIMI/FloodInundationMapper.html) to interactive online map libraries that can be downloaded in several commonly used electronic file formats. Each stream reach displayed on the latter Web site contains links to USGS National Water Information System graphs of the current stage and streamflow at USGS streamgage 02162500 , to which the inundation maps are referenced. A link also is provided to the NWS AHPS Web site (http://water.weather.gov/ahps/) so that users can obtain applicable information on forecasted peak stage. The estimated flood-inundation maps are displayed in sufficient detail to note the extent of flooding with respect to individual structures so that preparations for flooding and decisions for emergency response can be performed efficiently. Roadways and bridges were closely reviewed and are shown as shaded (partially or fully inundated and likely impassable) or not shaded (dry and passable) to facilitate emergency planning and use. Buildings that are shaded do not necessarily reflect full inundation but denote that bare earth surfaces in the vicinity of the buildings are inundated. When the water depth (as indicated in the Web Mapping Application by holding the cursor over an inundated area) in the vicinity of the building of interest exceeds any portion of that building's height, the structure can be considered partially to fully submerged, depending on the depth given.

\section{Disclaimer for Flood-Inundation Maps}

Inundated areas shown should not be used for navigation, regulatory, permitting, or other legal purposes. The USGS provides these maps "as-is" for a quick reference, emergency planning tool but assumes no legal liability or responsibility resulting from the use of this information.

\section{Uncertainties and Limitations for Use of Flood-Inundation Maps}

Although the flood-inundation maps represent the boundaries of inundated areas with a distinct line, some uncertainty is associated with these maps. The flood boundaries shown were estimated based on water stages (water-surface elevations) and streamflows at selected USGS streamgages. Watersurface elevations along the stream reaches were estimated by steady-state hydraulic modeling, assuming unobstructed flow, and using streamflows and hydrologic conditions anticipated at the USGS streamgage. The hydraulic model reflects the land-cover characteristics and any bridge, dam, or other hydraulic structures existing as of August 2012. Unique meteorological factors (timing and distribution of precipitation) may cause actual streamflows along the modeled reach to vary from those assumed during a flood, which may lead to deviations in the water-surface elevations and inundation boundaries shown. Additional areas may be flooded due to unanticipated conditions such as: changes in the streambed elevation or roughness, backwater into major tributaries along a main stem river, or backwater from localized debris or ice jams. The accuracy of the floodwater extent portrayed on these maps will vary with the accuracy of the digital elevation model used to simulate the land surface. Additional uncertainties and limitations pertinent to this study are described in the document accompanying this set of flood-inundation map sheets.

If this series of flood-inundation maps will be used in conjunction with National Weather Service (NWS) river forecasts, the user should be aware of additional uncertainties that may be inherent or factored into NWS forecast procedures. The NWS uses forecast models to estimate the quantity and timing of water flowing through selected stream reaches in the United States. These forecast models (1) estimate the amount of runoff generated by precipitation and snowmelt, (2) simulate the movement of floodwater as it proceeds downstream, and (3) predict the flow and stage (water-surface elevation) for the stream at a given location (AHPS forecast point) throughout the forecast period (every 6 hours and 3 to 5 days out in many locations). For more information on AHPS forecasts, please see: http://water.weather.gov/ahps/pcpn_and_ river forecasting.pdf. 


\section{Summary}

A series of estimated flood-inundation maps were developed by the U.S. Geological Survey (USGS) for a 3.95mile reach of the Saluda River from approximately 815 feet downstream from Old Easley Bridge Road to approximately 150 feet downstream from Saluda Lake Dam near Greenville, South Carolina. These maps, available at a USGS Web portal, in conjunction with the real-time stage data from the USGS streamgage Saluda River near Greenville, South Carolina (station 02162500), and National Weather Service flood-stage forecasts, can help to guide the general public in taking individual safety precautions and can provide local officials with a tool to efficiently manage emergency flood operations and flood-mitigation efforts.

The maps were developed using the U.S. Army Corps of Engineers HEC-RAS and HEC-GeoRAS computer programs to compute water-surface profiles and to delineate estimated flood-inundation areas for selected stream stages. The maps show estimated flood-inundation areas overlain on highresolution aerial imagery of the study area for stream stages between 6.0 feet and 20.0 feet (gage datum) at the Saluda River near Greenville, South Carolina, streamgage (station 02162500).

\section{References Cited}

Arcement, G.J., and Schneider, V.R., 1989, Guide for selecting Manning's roughness coefficients for natural channels and flood plains: U.S. Geological Survey Water-Supply Paper 2339, $38 \mathrm{p}$.

Bales, J.D., Wagner, C.R., Tighe, K.C., and Terziotti, Silvia, 2007, LiDAR-derived flood-inundation maps for realtime flood-mapping applications, Tar River Basin, North Carolina: U.S. Geological Survey Scientific Investigations Report 2007-5032, 42 p.

Burrus, S.A., and Pelissier, Joseph, 2011, The Greenville, South Carolina, flash flood of 29 July 2004: National Oceanic and Atmospheric Administration, National Weather Service, accessed November 29, 2012, at http:// www.erh.noaa.gov/gsp/localdat/cases/2004/29July ReedyFlood/29July_ReedyRiverFlood.html.
Federal Emergency Management Agency, 2004, Digital Flood Insurance Rate Map, Greenville County, December 2, 2004, accessed July 2012 at $h t t p: / / w w w . m s c . f e m a . g o v /$.

Federal Emergency Management Agency, 2008, Digital Flood Insurance Rate Map, Pickens County, April 16, 2008, accessed July 2012 at $h t t p: / / w w w . m s c . f e m a . g o v /$.

South Carolina Department of Natural Resources, 2010, LiDAR and related data products, accessed August 9, 2012, at http://www.dnr.sc.gov/GIS/lidar.html.

Trimble, 2012, Trimble R5 GPS Reciever, accessed August 13, 2012, at http://trl.trimble.com/docushare/dsweb/Get/ Document-468444/022543-491B_TrimbleR5_DS_0212_lr sec.pdf.

U.S. Army Corps of Engineers, Hydrologic Engineering Center, 2009, HEC-GeoRAS, GIS Tools for Support of HEC-RAS Using ArcGIS, User's Manual, version 4.2 [variously paged].

U.S. Army Corps of Engineers, Hydrologic Engineering Center, 2010, HEC-RAS River Analysis System, Hydraulic Reference Manual, version 4.1 [variously paged].

U.S. Census Bureau, 2012a, State and County QuickFacts, Greenville, South Carolina, accessed June 25, 2012, at http://quickfacts.census.gov/qfd/states/45/4530850.html.

U.S. Census Bureau, 2012b, State and County QuickFacts, South Carolina, accessed August 29, 2012, at http:// quickfacts.census.gov/qfd/states/45000.html.

U.S. Geological Survey, 2012, Water-resources data for the United States, Water Year 2011: U.S. Geological Survey Water-Data Report WDR-US-2011, site 02162500, accessed February 4, 2013, at http://wdr.water.usgs.gov/wy2011/ $p d f s / 02162500.2011 . p d f$.

Whitehead, M.T., and Ostheimer, C.J., 2009, Development of a flood-warning system and flood-inundation mapping for the Blanchard River in Findlay, Ohio: U.S. Geological Survey Scientific Investigations Report 2008-5234, 9 p. 
Publishing support provided by: Raleigh Publishing Service Center

Manuscript approved for publication January 15, 2013

For more information concerning this publication, contact:

Director, South Carolina Water Science Center

U.S. Geological Survey

720 Gracern Road

Suite 129

Columbia, SC 29210

(803) 750-6100

Or visit the South Carolina Water Science Center Web site at: http://sc.water.usgs.gov/ 

